At Lake Louise, there were calls again for a Global Strategy for Environmental Education. But I submit that we now have such a strategy: It is in place and has already begun functioning. Unlike other global strategies, this is a 'grassroots' or 'bottom-upwards' strategy. It is a network-a network of professional education societies and individuals who are committed to rigour in their relentless quest for knowledge. It is also a strategy for developing ecologically sustainable societies. It is the International Society For Environmental Education and its sister organization the World Council For The Biosphere.

CRAIG B. DAVIS, Secretary-General of WCB-ISEE Director, School of Natural Resources

The Ohio State University

2021 Coffey Road

Columbus

Ohio 43210

USA.

\title{
EDITORIAL
}

\section{Violence Deplored: Substitute Due Respect for Life and The Biosphere}

$\mathrm{T}$ he World Council For The Biosphere (WCB) and its complementary 'twin sister' the International Society For Environmental Education (ISEE) are effectively placed in their proper, action-engendering context by WCB-ISEE Secretary-General Craig B. Davis in the preceding Guest Editorial and by WCB Councillor Lynton K. Caldwell in his pivotal paper of this issue. WCB and ISEE are at once leading offshoots and active adopters of our World Campaign for The Biosphere, on which enough has already appeared in these columns. At the same time WCB and ISEE-which are especially featured in the four following contributions and elsewhere in this issue of our Journal-are auguries of another need (some would call it an imperative, if our world is to survive), namely peaceful co-existence rather than violent confrontation.

In advancing the concept of Our Biosphere as a harbinger of 'peace for all Mankind', we should re-emphasize the four basic truths that we, Mankind, being specimens of Homo sapiens of whatever kind, colour, denomination, or dimensions: (1) are an integral part of The Biosphere to which we now collectively contribute a major portion of its biomass while controlling very much more, (2) that The Biosphere is an integrated whole which can be jeopardized only at the greatest possible risk, (3) that Mankind and Nature are utterly dependent on The Biosphere's health and productivity for the wherewithal of life and that of future generations, but (4) that we are threatening this only life-support more and more gravely with our ever-increasing numbers and demophoric impact.

The main threats we have also detailed more than once in these columns or elsewhere, and in many cases spell out again in the next-following paper. But have we made enough of the waves of violence and terrorism which shock the world so frequently nowadays that we risk getting accustomed to them and even complacently apathetic about them? That seems to be a concomitant danger which must be faced, even as we deplore violence and plead for due respect for life and property.

Yet what are the origins of this widespread violence and why does it seem to get worse and worse? We have pondered on various possible explanations and come back to our usual basic one of 'too many people'. However, the increases in lawlessness seem to have been far more rapid of late than increases in human population or even its pressures (demophora) alone, and have involved countries in which the population is stable or even decreasing. Consequently another explanation must be sought, and we believe the media-especially television-are gravely to blame.

If one looks at almost any television show on either side of the Atlantic or often further afield nowadays, one will risk being confronted by all manner of violence or sheer nastiness - to the extent that such horrors will inevitably in time seem to be a normal way of life or at least a facet of modern life. That being so, especially the possessors of impressionable young minds will regrettably be apt to go out and perpetrate what they may have thus been moulded into regarding as 'the normal way of life', however pervertedly debauched or actually criminal it may be. Numerous instances have indeed been reported of such emulation, with perpetrators often admitting that they had got their ideas or even guidance from television, cinema, or the press-sometimes for quite heinous crimes, including planned murder (see, for example, the horrifying account in Reader's Digest, January 1983, pp. 49-53). This deplorably dangerous situation surely needs remedying, and could well be remedied, by suitable laws and their proper enforcement.

Instead of these horrors we would foster due respect for life, and due reverence for the solidly good things which it can offer.To be sure, it is easy to say that from our vantage-point of relatively good fortune; but circumstances have not always been easy, and latterly it has become increasingly difficult to maintain a multiplicity of joblets of which editing this Journal is only one. Yet we feel that the afore-mentioned concept of Our Biosphere as a harbinger of peace (as it can certainly be of prosperity if given a proper chance) can be of great spiritual solace and even practical help.

In terms of the ethics of human individuality cum interdependence: if all farmers, landowners, foresters, horticulturists, aquaculturists, and others responsible for the healthful maintenance of however small an area of our planet, would come to view it also as an integral and hence important part of The Biosphere, they would be the more likely to look after it as diligent stewardswhereupon, we believe, there would be less inclination to strife and violence of all kinds, including the waging of wars. Such concern should be felt and expressed with quasi-religious fervour and, with due reverence for life, could take the place of more orthodox religions and traditional disciplines whose widespread erosion is another sad feature of our techno-scientific age. 